2009

\title{
Guantanamo, Habeas Corpus, and Standards of Proof: Viewing the Law through Multiple Lenses
}

Matthew C. Waxman

Follow this and additional works at: https://scholarlycommons.law.case.edu/jil

\section{Recommended Citation}

Matthew C. Waxman, Guantanamo, Habeas Corpus, and Standards of Proof: Viewing the Law through Multiple Lenses, 42 Case W. Res. J. Int'l L. 245 (2009)

Available at: https://scholarlycommons.law.case.edu/jil/vol42/iss1/11

This Article is brought to you for free and open access by the Student Journals at Case Western Reserve University School of Law Scholarly Commons. It has been accepted for inclusion in Case Western Reserve Journal of International Law by an authorized administrator of Case Western Reserve University School of Law Scholarly Commons. 


\title{
Guantánamo, Habeas Corpus, AND STANDARds of Proof: VIEWING THE LAW THROUGH MULTIPLE LENSES
}

\begin{abstract}
Matthew C. Waxman ${ }^{*}$
The Supreme Court held in Boumediene v. Bush that Guantánamo detainees have a constitutional right to habeas corpus review of their detention, but it left to district courts in the first instance responsibility for working through the appropriate standard of proof and related evidentiary principles imposed on the government to justify continued detention. This article argues that embedded in seemingly straightforward judicial standard-setting with respect to proof and evidence are significant policy questions about competing risks and their distribution. How one approaches these questions depends on the lens through which one views the problem: through that of a courtroom concerned with evidence or through that of a battlefield clouded by imperfect intelligence. All three branches of government should play significant roles in answering these questions, which are critical to establishing sound detention policy.
\end{abstract}

\section{INTRODUCTION}

The Supreme Court held in Boumediene v. Bush that Guantánamo detainees have a constitutional right to habeas corpus review of their detention. ${ }^{1}$ However, the Court left to district courts in the first instance responsibility for working through the many procedural and substantive issues that would govern resulting habeas proceedings. ${ }^{2}$ While mandating that Guantánamo detainees receive access to U.S. federal courts empowered to correct errors after "meaningful review of both the cause for detention and the Executive's power to detain,", the Court emphasized that it was "not ad-

\footnotetext{
Associate Professor, Columbia Law School; Adjunct Senior Fellow, Council on Foreign Relations; Member of the Hoover Institution Task Force on National Security and Law. I thank the following individuals for their helpful comments and guidance: Robert Chesney, Philip Hamburger, Dan Richman, and Benjamin Wittes. I also thank Neta Levanon for her excellent research assistance.

1 See 128 S. Ct. 2229, 2262 (2008).

2 See Del Quentin Wilber, Detention Challenges Are Far Off for Many, WASH. Post, July 31, 2009, at A06, available at http://www.washingtonpost.com/wp-dyn/content/article/2009/ 07/30/AR2009073004116.html. See also RichaRD H. FALlON, JR. ET AL., HART AND WeChSler's the Federal Courts And the Federal System 1163 (2009) (“To say that the Suspension clause affirmatively guarantees a right to habeas corpus leaves open a welter of issues about the scope of that right.").

3 Boumediene v. Bush, 128 S. Ct. 2229, 2269 (2008).
} 
dress[ing] the content of the law that governs petitioners' detention." ${ }^{\prime 4}$ The particular questions I focus on here-questions with procedural and substantive, domestic and international law dimensions - concern the standard of proof and related evidentiary principles imposed by habeas courts on the government to justify continued detention.

In a 2008 article I compared detention decision-making to military targeting decision-making and argued that international law rules governing targeting could be imported by analogy to help derive answers to the question: If a state is engaged in armed conflict with a transnational terrorist organization, and the state decides to detain or continue detaining someone fighting on the enemy's behalf, how certain ought the state have to be in its assessment of that individual's identity and enemy status? $?^{5}$ This Article examines how district courts have so far dealt with this issue.

This article argues that embedded in seemingly straightforward judicial standard-setting with respect to proof and evidence are significant policy questions about competing risks and their distribution. How one approaches these questions depends on the lens through which one views the problem: through that of a courtroom concerned with evidence or through that of a battlefield clouded by imperfect intelligence. The article concludes that all three branches of government should play significant roles in working through these questions, which are critical to establishing sound policy not only for those currently detained at Guantánamo, but also for those likely to be captured in the future struggle against al-Qaida.

\section{STANDARD OF PROOF ISSUES}

One question that quickly arises in habeas proceedings reviewing enemy combatant detentions is the appropriate standard of proof: to what level of certainty must the government prove the factual bases of its detention decision? For all enemy combatant detentions until Hamdi v. Rumsfeld ${ }^{6}$ and Boumediene, ${ }^{7}$ and since then for detentions of al-Qaida and allied fighters pursuant to war powers outside the U.S. or Guantánamo, the executive has dealt with this issue unilaterally and internally-i.e., through its own judgments of legally necessary factual certainty about a suspect's identity and conduct to warrant and authorize detention. Once habeas rights or some other form of judicial review apply, however, courts must quickly confront this issue more formally and explicitly. The courts' assessments of the government's claims about particular suspects must be measured against some

\footnotetext{
Id. at 2277 .

See Matthew C. Waxman, Detention as Targeting: Standards of Certainty and Detention of Suspected Terrorists, 108 CoLuM. L. REV. 1365 (2008).

6542 U.S. 507 (2004).

$7 \quad 128$ S. Ct. 2229 (2008).
} 
standard, whether it be a low one such as the "some evidence" standard or a high one like "clear and convincing" or "beyond reasonable doubt." 8

At the time of this writing, all district courts to consider Guantánamo habeas cases have reached or adopted the same answer: that courts should apply the "preponderance of evidence" standard-i.e., more probable than not-in assessing whether an individual is properly detained under the executive's detention power, ${ }^{9}$ however that power is defined. ${ }^{10}$ There was initially some dispute over this issue in the many consolidated cases before Judge Hogan. ${ }^{11}$ Detainees' counsel urged the court to use a "clear and convincing" standard, ${ }^{12}$ the standard the Supreme Court has held to apply in some other contexts where the government seeks to impose substantial deprivation of liberty. ${ }^{13}$ The government urged instead that it ought only have to put forth credible evidence that the petitioner meets the proper detention criteria, after which the burden should shift to petitioner to rebut it with more persuasive evidence. ${ }^{14}$ Ultimately, the government urged a preponderance of evidence standard, distinguishing the cases cited by petition-

8 The "beyond reasonable doubt" standard for criminal conviction, held to be constitutionally required in In re Wiship, 397 U.S. 358 (1970), reflects one possible balance of competing harms with respect to criminal suspects. As Blackstone explained, "it is better that ten guilty persons escape than that one innocent suffer." 4 William BLACKSTONE, COMMENTARIES *358 (1853). The question here is to what extent the threat of terrorism requires recalibrating that balance.

9 See, e.g., Ali Ahmed v. Obama, 613 F. Supp. 2d 51, 53 (D.D.C. 2009); Bihani v. Obama, 594 F. Supp. 2d 35, 38 (D.D.C. 2009); Sliti v. Bush, 592 F. Supp. 2d 46, 49 (D.D.C. 2008); El Gharani v. Bush, 593 F. Supp. 2d 144, 146 (D.D.C. 2009); Al Alwi v. Bush, 593 F. Supp. 2d 24, 27 (D.D.C. 2008); Hammamy v. Obama, 604 F. Supp. 2d 240, 242 (D.D.C. 2009); Basardh v. Obama, 612 F. Supp. 2d. 30, 35 n.12 (D.D.C. 2009); Al Ginco v. Obama, 2009 U.S. Dist. LEXIS 53932, at 6-7 (D.D.C. 2009); Boumediene v. Bush, 579 F. Supp. 2d 191, 195-96 (D.D.C. 2008); Parhat v. Gates, 532 F.3d 834, 840 (D.C. Cir. 2008); Al Mutairi v. United States, Civil Action No. 02-828 (CKK), 2009 WL 2364173, at*1 (D.D.C. July 29, 2009).

10 On the difficult legal and policy issues of defining detention authority in the context of terrorism, see generally Matthew C. Waxman, Administrative Detention of Terrorists: Why Detain, and Detain Whom? 3 J. NAT'L SECURITY L. \& POL'Y 1 (2009).

11 See Petitioner's Joint Memorandum of Law Addressing Procedural Framework Issues at 11-13, In re Guantanamo Bay Detainee Litigation, Misc. No. 08-442 (TFH) (D.D.C. July 25, 2008), available at http://dockets.justia.com/docket/court-dcdce/case_no-1:2008mc00442/ case_id-131990/[hereinafter Procedural Framework Memorandum].

12 Id. at $11-13$.

13 See, e.g., Kansas v. Hendricks, 521 U.S. 346, 356 (1997) (discussing the civil commitment of sex offenders); Foucha v. Louisiana, 504 U.S. 71, 81 (1992) (discussing the continued commitment of criminal suspects found not guilty by reason of insanity); United States v. Salerno, 481 U.S. 739, 750 (1987) (discussing pre-trial detention based on alleged dangerousness).

14 See Procedural Framework Memorandum, supra note 11, at 15. 
ers as irrelevant in the wartime context. ${ }^{15}$ The district court sided with the government, ${ }^{16}$ and since then other district court judges have uniformlyand without analysis - applied the same standard in Guantánamo habeas cases. Courts probably gravitated toward the preponderance standard for these cases in part because preponderance of evidence is typically the standard presumptively applied in most habeas contexts. ${ }^{17}$

Should preponderance of evidence be the proof standard in these cases? The dearth of judicial analysis of this question at any level is surprising given how often the outcome of these cases will centrally turn on this question. ${ }^{18}$ After all, the fundamental problem out of which these cases grow is a conflict against a transnational terrorist organization that does not openly mark its members and supporters as such, but instead tries to obfuscate their identity. ${ }^{19}$ Almost every seriously contested case will involve a dispute about the strength of the government's information supporting its assessment. And in those cases for which habeas review will make a meaningful difference between release or continued detention, the government's case will likely include judgments made in the murky fog of war, reliance on intelligence supplied by foreign governments, or assessments developed based on patterns of suspects' behavior in relation to what is known about the enemy. ${ }^{20}$

15 See Government's Response to Petitioner's Filing on Framework Procedural Issues at 8-11, In re Guantanamo Bay Detainee Litigation, Misc. No. 08-442 (TFH) (D.D.C. Aug. 1, 2008), available at http://dockets.justia.com/docket/court-dcdce/case_no-1:2008mc00442/ case_id-131990/.

16 See Case Management Order at 4, In re Guantanamo Bay Detainee Litigation, Misc. No. 08-0442 (TFH) (D.D.C. Nov. 6, 2008), available at http://dockets.justia.com/docket/ court-dcdce/case no-1:2008mc00442/case_id-131990/.

17 See 2 Randy Hertz \& James S. Liebman, Federal Habeas Corpus Practice AND PROCEDURE 1497 (2001) (explaining that because habeas proceedings are generally considered civil in nature, the presumptive standard of proof is preponderance of evidence).

18 For a thorough scholarly examination of this issue from the perspective of domestic habeas law, concluding that preponderance standard is an acceptable approach in this context, see Richard H. Fallon, Jr. \& Daniel J. Meltzer, Habeas Corpus Jurisdiction, Substantive Rights, and the War on Terror, 120 HARV. L. ReV 2032, 2092-93 (2007).

19 The Israeli Supreme Court recently made this point in upholding Israel's Internment of Unlawful Combatants Law. See CrimA 6659/06 Anonymous v. State of Israel [2008], at 20 (Isr.), translation available at http://elyon2.court.gov.il/files_eng/06/590/066/n04/06066590. n04.pdf ("[U]nlawful combatants do not as a rule carry any clear and unambiguous indication that they belong to a terrorist organization." (citation omitted)).

20 Many of the cases considered by Combatant Status Review Tribunals at Guantánamo involved plausible denials or silence on the detainee pitted against plausible inferences drawn from intelligence sources. See Benjamin Wittes, Law and the Long War: The Future of Justice In the Age OF Terror 72-99 (2008). See also Al Odah v. United States, Civil Action No. 02-828 (CKK), 2009 WL 2730489, at*15 (D.D.C. Aug. 24, 2009) (stating that "the Court finds that the Government has met its burden based on the evidence in the record with- 
Consider, for example, two cases that appear to fall close to but ultimately settle on different sides of the preponderance line. In Al Mutairi v. United States, the district court implied that the government narrowly failed to justify detention of a Kuwaiti national alleged to have joined al-Qaida and an affiliated terrorist group. Although the government established that the petitioner's activities and travel closely matched patterns of al-Qaida agents, the court went on to find that:

[T]he Government has at best shown that some of Al Mutairi's conduct was consistent with persons who may have become a part of al Qaida or an associated force of al Qaida, but there is nothing in the record beyond speculation that $\mathrm{Al}$ Mutairi did, in fact, train with or otherwise become a part of either or both of those organizations. While Al Mutairi's described travels within Afghanistan lack credibility, the Government has not supplanted Al Mutairi's version of his travels with sufficiently credible and reliable evidence to meet its burden of persuasion by a preponderance of the evidence. ${ }^{21}$

In Boumediene v. Bush, on remand, the district court ordered the government to release five of six native Algerians taken by the U.S. government in Bosnia. ${ }^{22}$ As to the sixth, however, the court held that:

[T]he Government has met its burden by providing additional evidence that sufficiently corroborates its allegations from [an] unnamed source that Bensayah is an al-Qaida facilitator. . . . In order to establish Bensayah's role as an al-Qaida facilitator, the Government depends on the same intelligence information described above [and found to be unpersuasive with respect to the other five], but also puts forth a series of other intelligence reports based on a variety of sources and evidence .... ${ }^{23}$

Not only do this sixth case in Boumediene and Al Mutairi appear to fall close to the preponderance line, but the courts' descriptions also highlight how easily different judges viewing the same evidence could reach different conclusions, either because they weigh certain pieces of evidence differently or because they view the standard differently. ${ }^{24}$ It is easy to

out specifically identifying that the Taliban-run camp attended by $\mathrm{Al}$ Odah was, in fact, $\mathrm{Al}$ Farouq. ").

21 Al Mutairi v. United States, Civil Action No. 02-828 (CKK), 2009 WL 2364173, at*1 (D.D.C. July 29, 2009).

22 Boumediene v. Bush, 579 F. Supp. 2d 191, 197-98 (D.D.C. 2008).

23 Id. at 198.

24 See C.M.A. McCauliff, Burden of Proof: Degrees of Belief, Quanta of Evidence, or Constitutional Guarantees?, 35 VAND. L. REV. 1293 (1982) (documenting ambiguity and different interpretations of proof burdens among judges). For another example in the Guantánamo context, consider Awad v. Obama, Civil Action No. 05-CV-2379 (D.D.C. Aug. 12, 2009), available at https://ecf.dcd.uscourts.gov/cgi-bin/show_public_doc?2005cv2379-178. 
wonder after reading these two decisions in full whether any principled line drawing distinguishes them.

One way of looking at the standard of proof question is through the lens of domestic law. Viewing the issue as one of procedural due process and applying the Mathews v. Eldridge $e^{25}$ balancing test, the Supreme Court in Hamdi made clear with respect to citizen-detainees that risk of erroneous detention is the key individual interest to be protected. ${ }^{26}$ The Mathews balancing test assesses the sufficiency of procedural protections based on the importance of the individual interest at stake, the state's interests, the risk of an erroneous deprivation of the individual's interests, and the probable value of additional procedural safeguards. ${ }^{27}$ So considering these factors in the context of detaining al-Qaida suspects, how much risk of error is appropriate? Neither Hamdi - which, in the case of a citizen-detainee, called for a "fair opportunity to rebut the Government's factual assertions before a neutral decisionmaker" ${ }^{28}$ - nor the Supreme Court's extension of Hamdi's principles in Boumediene - requiring a "meaningful opportunity to demonstrate that [a detainee] is being held pursuant to "the erroneous application or interpretation' of relevant law" 29 - answer that question. True, Justice O'Connor's plurality opinion in Hamdi rejects both the government's suggestion that it need only show a court "some evidence" to back up its decisions - the lowest proof standard used by courts - as well as the Petitioner's suggestion that criminal trial standards are required. ${ }^{30}$ But that still leaves a lot of room in between. ${ }^{31}$

In that case, Judge Robertson acknowledged that "the case against Awad is gossamer thin." $I d$. at slip op. 20. He goes on to say that "[t]he evidence is of a kind fit only for these unique proceedings [REDACTED]" but in the end, it seems "more likely than not that Awad was, for some period of time, 'part of' al Qaida" and the correlation of names on the list "clearly tied to al Qaida make it more likely than not that he knew the al Qaida fighters at the hospital and joined them in the barricade." Id. at slip op. 20-21.

25424 U.S. 319, 335 (1976).

26 See Hamdi v. Rumsfeld, 542 U.S. 507, 532-33 (2003).

27 Mathews v. Eldridge, 424 U.S. 319, 335 (1976).

28 Hamdi, 542 U.S. at 533. See also Fallon \& Meltzer, supra note 18, at 2091 ("Although we . . . approve of the plurality's basic approach in Hamdi, its opinion is regrettably unclear on crucial points, including the burden of persuasion that the government must meet to justify detaining an American citizen as an enemy combatant.").

29 Boumediene v. Bush, 128 S. Ct. 2229, 2238 (2008) (quoting INS v. St. Cyr, 533 U.S. 289, 302 (2001)).

30 See Hamdi, 542 U.S. at 537-39. Justice O'Connor may have hinted also at the appropriateness of the preponderance standard when she said that "once the Government puts forth credible evidence that the habeas petitioner meets the enemy-combatant criteria, the onus could shift to the petitioner to rebut that evidence with more persuasive evidence that he falls outside the criteria." Id. at 534.

31 See Boumediene, $128 \mathrm{~S}$. Ct. at 2271 ("[t]he extent of the showing required of the government in these cases is a matter to be determined."); see also Daniel J. Meltzer, Habeas 
One of the most interesting applications of the minimal Hamdi guidance as to the standard of proof issue appears in the district court's consideration of Boumediene v. Bush on remand. ${ }^{32}$ In rejecting the government's claims that petitioner fell within the executive's detention authority, the court explained:

[W] hile the information in the classified intelligence report, relating to the credibility and reliability of the source, was undoubtedly sufficient for the intelligence purposes for which it was prepared, it is not sufficient for the purposes for which a habeas court must now evaluate it. To allow enemy combatancy to rest on so thin a reed would be inconsistent with this Court's obligation under the Supreme Court's decision in Hamdi to protect petitioners from the risk of erroneous detention. ${ }^{33}$

It is not so clear, however, how thick or thin a reed Hamdi requires. Procedural due process doctrine is not about preventing all errors, but rather reducing their likelihood to a legally appropriate probability. Standing alone, the holdings of Hamdi and Boumediene offer little guidance on what level of error is appropriate. This lack of guidance exists because setting that standard depends critically on a balance of risks and a notion of how these risks should be shared or distributed, issues that so far courts have been cautious to tackle. ${ }^{34}$ As Justice Harlan explained in In re Winship:

Because the standard of proof affects the comparative frequency of these two types of erroneous outcomes [false positives and false negatives], the choice of the standard to be applied in a particular kind of litigation should, in a rational world, reflect an assessment of the comparative social disutility of each. ${ }^{35}$

Corpus, Suspension, and Guantánamo: The Boumediene Decision, 2008 Sup. Cт. Rev. 1, 58 (2008) ("Habeas courts will face a complex of questions falling under the general heading of "scope of review" including "the deference (if any) that they should give to various determinations by CSRTs ....").

32579 F. Supp. 2d 191 (D.D.C. 2008).

33 Id. at 197 (emphasis in original).

34 The Fourth Circuit struggled with this issue in Al-Marri v. Pucciarelli, 534 F.3d 213, 274 (4th Cir. 2008), cert. granted, Al-Marri v. Pucciarelli, 129 S. Ct. 680 (2008), vacated by, remanded by, application granted by Al-Marri v. Spagone, 129 S. Ct. 1545 (2009) (Traxler, J., concurring in the judgment) ("In the words of Matthews, [the proposed proof standards and burdens] would sufficiently address the 'risk of an erroneous deprivation' of a detainee's liberty interest while eliminating certain procedures that have question additional value in light of the burden on the [g]overnment.") (quoting Hamdi v. Rumsfeld, 542 U.S. 507, 534 (2003)).

35397 U.S. 358, 371 (1970) (Harlan, J., concurring). See also Dale A. Nance, Evidential Completeness and the Burden of Proof, 49 Hastings L.J. 621, 622 (1998) ("The now conventional understanding of the burden of proof is that the level or weight of the burden of 
As alluded to earlier, ${ }^{36}$ in other contexts involving substantial deprivation of liberty, courts have required the government to justify its case by clear and convincing evidence. In Addington v. Texas, for example, the Supreme Court held that the clear and convincing standard is constitutionally required in civil commitment hearings. ${ }^{37}$ In doing so the Court explained that " $t \mathrm{t}]$ he standard [of proof] serves to allocate the risk of error between the litigants and to indicate the relative importance attached to the ultimate decision.." ${ }^{38}$ In United States v. Salerno, the Supreme Court upheld pretrial detention under the federal Bail Reform Act relying heavily on its view that the Act's requirement of "clear and convincing evidence that no conditions of release can reasonably assure the safety of the community or any person" struck an appropriate balance liberty-security balance. ${ }^{39}$

In the Guantánamo context, however, setting proof standards is especially difficult because the factors to be balanced are so weighty in multiple directions - they include, among many other considerations, the harm of erroneous detention under severe conditions, perhaps indefinitely, versus the risk of letting a dangerous terrorist go free. ${ }^{40}$ Both of these are arguably

persuasion is determined by the expected utilities associated with correct and incorrect alternative decisions.").

36 See supra notes 12-13 and accompanying text.

37441 U.S. 418 (1979).

38 Id. at 423.

39481 U.S. 739,750 (1987) (citing 18 U.S.C. § 3142(f)). See also Foucha v. Louisiana, 504 U.S. 71, 81 (1992) (explaining that the clear and convincing standard applicable in $\mathrm{Sa}$ lerno was critical to that holding).

40 Judge Posner poses this question but does not provide a specific answer:

Requiring proof beyond a reasonable doubt in criminal cases causes many guilty defendants to be acquitted and many other guilty persons not to be charged in the first place. We accept this as a price worth paying to protect the innocent. But ordinary crime does not imperil national security; modern terrorism does, so the government's burden of proof should be lighter, though how much lighter is a matter of judgment.

Richard A. Posner, Not a Suicide Pact: The Constitution in a Time of National EMERGENCY 64-65 (2006). This point arose in Zadvydas v. Davis, 533 U.S. 678 (2001), in which the Court made clear that indefinite administrative detention of a removable alien would raise constitutional due process concerns, but also noted that a statutory scheme directed at suspected terrorists might change its analysis in light of heightened security stakes. See id. at 691.

It is important to note, however, that the threat level among detainees at Guantánamo and elsewhere varies significantly, and there is considerable debate about "recidivism" rates among those released from Guantánamo. Compare U.S. DEPARTMENT OF DEFENSE FACT Sheet, Former Guantanamo Detainee Terrorism Trends (Apr. 7, 2009), available at www.defenselink.mil/news/returntothefightfactsheet2.pdf (reporting fourteen percent of former Guantánamo detainees likely reengaged in terrorist activities) (last visited Oct. 31, 2009), with Peter Bergen \& Katherine Tiedemann, Commentary: How Many Gitmo Prisoners Return to Fight?, CNN, July 21, 2009, http://www.cnn.com/2009/POLITICS/07/20/ 
greater dangers than those considered in most civil or criminal detention contexts. ${ }^{41}$ And for that matter, how one views the liberty harms depends on whether one begins from a baseline of peacetime, where individual liberty is the strongly protected interest, or wartime, where liberty deprivations are more widely shared and procedural protections are often curtailed, or some baseline in between.

Viewed through the lens of the international law of war the same questions arise but by a different analytic route. The Obama administration has taken the position in ongoing habeas litigation that its detention authority pursuant to the 2001 Authorization for the Use of Military Force should be interpreted by reference to the international law of armed conflict, ${ }^{42}$ and courts have generally agreed with that approach. If courts are looking to international law to discern the substantive bounds of executive detention power in this context, should they not also look to those same sources of law to discern the standard of proof? ${ }^{43}$ If habeas is an error correction mechanism, and the Supreme Court made clear in Boumediene that habeas is a flexible tool to be adapted to particular contexts, then its standards should be informed by the substantive law whose bounds it is policing.

On the face of their opinions, the habeas courts are not looking to the law of war for guidance on the proof standard issue, likely seeing it as a procedural question rather than a substantive one. Even if courts did, however, the law of war does not provide clear guidance.

International law of detention in warfare contains little definitive guidance on the standard of proof or certainty issue probably for two overarching reasons. First, in the limited-duration, conventional warfare between professional armies out of which the modern law developed, the issue of detention review standards rarely needed such precise guidance. Second, the appropriate standard of proof or certainty in warfare is very contextdependent. ${ }^{44}$ Article 5 of the the Third Geneva Convention, for example, requires that:

bergen.guantanamo/index.html (disputing Defense Department figures) (last visited on Oct. 31, 2009).

41 See Zadvydas v. Davis, 533 U.S. 678, 690-91, 696 (2001) (stating that due process analysis with respect to immigration detention might be different if it involved suspected terrorists or special national security needs).

42 See, e.g., Respondents' Memorandum Regarding the Government's Detention Authority Relative to Detainees Held at Guantanamo Bay, In re Guantanamo Bay Detainee Litigation, Misc. No. 08-442 (TFH) (D.D.C. Mar. 13, 2009), available at http://www.usdoj.gov/ opa/documents/memo-re-det-auth.pdf .

43 See INS v. St. Cyr, 533 U.S. 289, 301 (2001) ("At its historical core, the writ of habeas corpus has served as a means of revieing the legality of Executive detention . . .."). On the law of war and detention authorities, see generally Ryan Goodman, The Detention of Civilians in Armed Conflict, 103 AM. J. INT'L L. 48 (2009).

44 See Waxman, supra note 5, at 1379-84. 
Should any doubt arise as to whether persons, having committed a belligerent act and having fallen into the hands of the enemy, belong to any of [the combatant categories established by the Geneva Conventions], such persons shall enjoy the protections of the present Convention until such time as their status has been determined by a competent tribunal. ${ }^{45}$

But Article 5 says nothing about what level of certainty a "competent tribunal" should apply in resolving any doubt. ${ }^{46}$

Longstanding U.S. military regulations based on Article 5 of the Third Geneva Convention call for battlefield review of questionable detentions by a panel of officers applying a preponderance of evidence standard, ${ }^{47}$ and in her plurality opinion in Hamdi, Justice O'Connor pointed favorably toward these standards as a model that might satisfy due process. ${ }^{48}$ But it is not clear from these military regulations whether the U.S. military regards the preponderance standard as legally compelled or prudentially warranted, nor whether it would regard a higher standard as legally appropriate in some contexts. Looking abroad, there is very little clear state practice on this question from which to measure opinio juris. ${ }^{49}$

As an alternative approach to filling this gap, I previously argued that the principles of targeting law in warfare could be extrapolated to provide guidance on the standard of proof or certainty issue with respect to non-criminal terrorist detention. The "reasonable care" requirement with respect to verifying the targets of lethal force amid factual uncertainty could be adapted to the detention context. I argued, based on general law of war principles, that the appropriate standard of certainty required to justify detention at any point in time depended on a balance between military necessity or security concerns and humanitarian or liberty interests, and should take

45 Geneva Convention Relative to the Treatment of Prisoners of War art. 5, Aug. 12, 1949, 6 U.S.T. 3316, 75 U.N.T.S. 135 (1950).

46 The International Committee of the Red Cross (ICRC) has developed recommended procedural guidelines that should apply in such cases. See InT'L COMM. OF THE Red Cross, INTERNATIONAL HUMANITARIAN LAW AND THE CHALlENGES OF CONTEMPORARY ARMED CONFLICTS at Annex 1 (2007), available at http://www.icrc.org/web/eng/siteeng0.nsf/ html/ihl-30-international-conference-101207. See also Jelena Pejic, Procedural Principles and Safeguards for Internment/Administrative Detention in Armed Conflict and Other Situations of Violence, 87 INT'L REV. RED CROSS 375 (2005).

47 See U.S. Army, Enemy Prisoners of War, Retained Personnel, Civilian InterneES AND OTHER DetAineEs, AR 190-8, at § 1-6(9) (1997), available at http://www.au.af.mil/ au/awc/awcgate/law/ar190-8.pdf ("Following the hearing of testimony and the review of documents and other evidence, the Tribunal shall determine the status of the subject of the proceeding in closed session by majority vote. Preponderance of evidence shall be the standard used in reaching this determination.").

48 Hamdi v. Rumsfeld, 542 U.S. 507, 538-39 (2004).

49 See Robert Chesney \& Jack Goldsmith, Terrorism and the Convergence of Criminal and Military Detention Models, 60 StAn. L. REV. 1079, 1089 (2008). 
into account whether greater accuracy-producing procedures are reasonably available. ${ }^{50}$

Note, however, that viewing the problem of proof or certainty through the lens of warfare takes the legal question of appropriate assessment standards back to the same questions about competing values and policy interests demanded by Mathews v. Eldridge: ${ }^{51}$ What are the individual interests at stake with respect to errors? What are the state interests at stake? And what steps could the government take - and at what cost or burden - to reduce errors? ${ }^{52}$ This is not to suggest that the preponderance standard being used by habeas courts is wrong - in fact, when the Department of Defense established Combatant Status Review Tribunals at Guantánamo in the wake of Hamdi and Rasul v. Bush, ${ }^{53}$ its applicable guidelines also called for using the preponderance standard, ${ }^{54}$ implying that the executive regards the preponderance standard as the appropriate standard as well. Rather, this analysis suggests the need for more reasoned consideration of proof standards in this context given the unique problems, stakes, and risks associated with decision-making.

Moreover, the balancing of these competing risks through procedural regulation cannot be divorced completely from important substantive legal issues, such as the scope of the executive's detention power. As John Jeffries and Paul Stephan have observed in the criminal law context:

Winship's insistence on the reasonable-doubt standard is thought to express a preference for letting the guilty go free rather than risking conviction of the innocent. This value choice, however, cannot be implemented by a purely procedural concern with burden of proof. . . . A normative principle for protecting the "innocent" must take into account not only the certainty with which facts are established but also the selection of facts to be proved. A constitutional policy to minimize the risk of convicting the "innocent" must be grounded in a constitutional conception of what may constitute "guilt." Otherwise "guilt" would have to be proved with certain-

\footnotetext{
50 See Waxman, supra note 5, at 1402-20.

51494 U.S. 319,335 (1979).

52 See supra notes 25-27.

53 Rasul v. Bush, 542 U.S. 466 (2004).
}

54 See Memorandum of Paul Wolfowitz, Deputy Sec'y of Def., to the Sec'y of the Navy at 3 (July 7, 2004), available at http://www.defenselink.mil/news/Jul2004/d20040707review. pdf. Deputy Secretary of the Navy Gordon England explained the standard a bit differently in announcing the establishment of the CSRT process: "[W]e'll look at all the data dealing with their classification as an enemy combatant; ... . [a]nd the standard . . . will be reasonableness. It will be what would a reasonable person conclude." See Gordon England, Sec'y of the Navy, Briefing on Combatant Status Review Tribunal (CSRT) (July 9, 2004), available at http://www.defenselink.mil/transcripts/transcript.aspx?transcriptid=2777. 
ty, but the legislature could define "guilt" as it pleased, and the grand ideal of individual liberty would be reduced to an empty promise. ${ }^{55}$

In other words, the extent to which a proof standard prevents "errors" depends in part on how the factual predicate to be proven is defined-in this case, what does it mean to be an enemy fighter subject to the executive's wartime detention authority? A very broadly defined substantive authority even coupled with a strict proof standard may be no better at accurately culling true threats than a tightly drawn authority coupled with a loose proof standard. Thinking through the standard of proof question carefully can therefore help both to devise substantive detention law and prevent its circumvention.

\section{EVIDENTIARY SCRUTINY ISSUES}

The standard of proof issue is, of course, linked inextricably to questions about quality of evidence: on what types of information should a court base its assessment in reviewing executive detention? It is not the intention of this article to delve deeply into the many specific evidence law issues that are likely to arise in Guantánamo habeas cases, but rather to draw observations about the way courts have approached the issue generally. Again, sufficiency or quality of evidence issues can be viewed through multiple lenses: evidence versus intelligence, and courtroom versus battlefield. And again, lurking beneath these seemingly routine court rulings about evidence standards are major substantive and institutional questions about the nature of the conflict with al-Qaida and courts' proper role in regulating it.

The executive originally took the position in detainee litigation that the designation of an individual as an enemy fighter is a judgment that courts should not second-guess. In its brief to the Supreme Court in Hamdi, the government argued that "[a] commander's wartime determination that an individual is an enemy combatant is a quintessentially military judgment, representing a core exercise of the Commander-in-Chief authority." ${ }^{, 56}$ It argued from a functional standpoint that courts should not second-guess assessments of disputed facts because, "[e]specially in the course of hostilities, the military through its operations and intelligence-gathering has an unmatched vantage point from which to learn about the enemy and make judgments as to whether those seized during a conflict are friend or foe." 57 And from a constitutional separation of powers standpoint, the government

55 John Calvin Jeffries, Jr. \& Paul B. Stephan III, Defenses, Presumptions, and Burden of Proof in the Criminal Law, 88 YALE L.J. 1325, 1347 (1979).

56 Brief for the Respondents, Hamdi v. Rumsfeld, 2004 WL 724020, at*25.

57 Id. 
argued that courts should avoid "embroiling [themselves] in a factual dispute about a battlefield capture halfway around the world." ${ }^{58}$ Anticipating the response that many detainees at Guantánamo were not captured amid battle in a combat zone, the government further argued that " $[t]$ he unconventional nature of the current armed conflict only makes such deference more appropriate" because "[t]he enemy in the current conflict purposely blurs the lines between combatants and non-combatants by refusing to wear a uniform or distinctive insignia and attempting to blend into the civilian population." 59 The government made similar arguments in its Supreme Court brief in Rasul v. Bush: "The 'enemy' status of aliens captured and detained during war is a quintessential political question on which the courts respect the actions of the political branches." ${ }^{\prime 0}$ The government further argued that "courts have ... no judicially-manageable standards[] to evaluate or second-guess the conduct of the President and the military" on such matters. ${ }^{61}$

The Supreme Court flatly rejected the executive's argument that assessments of who is or is not an enemy fighter in an ongoing war lie outside the sphere of judicial competence and authority. In her plurality opinion in Hamdi, Justice O'Connor emphasizes: "In so holding, we necessarily reject the Government's assertion that separation of powers principles mandate a heavily circumscribed role for courts in such circumstances," and that "courts must forgo any examination of the individual case." ${ }^{62}$ In Boumediene, the Court further explained that:

Where a person is detained by executive order, rather than, say, after being tried and convicted in a court, the need for collateral review is most pressing. ... Habeas corpus proceedings need not resemble a criminal trial .... But the writ must be effective. The habeas court must have sufficient authority to conduct a meaningful review of both the cause for detention and the Executive's power to detain. ${ }^{63}$

The Court went on to say that:

For the writ of habeas corpus, or its substitute, to function as an effective and proper remedy in this context, the court that conducts the habeas proceeding must have the means to correct errors that occurred during the [Combatant Status Review Tribunal] proceedings. This includes some au-

\footnotetext{
$58 \quad$ Id. at $* 27$.

$59 \quad$ Id. at $* 31$.

60 Brief for the Respondents, Rasul v. Bush, 2004 WL 425739, at*35.

$61 \quad$ Id. at $* 37$ n. 19 .

62 Hamdi v. Rumsfeld, 542 U.S. 507, 535-36 (2004).

63 Boumediene v. Bush, 128 S. Ct. 2229, 2269 (2008).
} 
thority to assess the sufficiency of the Government's evidence against the detainee. $^{64}$

What these Supreme Court holdings do not explain, however, is how habeas courts should assess the sufficiency of information relied upon by the executive in its decisions. Boumediene calls for "meaningful" review of the executive's assessment and for "some" authority to consider the sufficiency of the government's information. But Boumediene provides very little guidance as to the rigor with which courts should independently scrutinize that information or the specific rules and standards by which information should be considered or rejected. ${ }^{65}$

Against that backdrop, some district courts have adopted fairly aggressive interpretations of their evidentiary gatekeeping role-i.e., what kind of information comes in during hearings - and of their fact-finding role in appraising it. ${ }^{66}$ Recall from above, for example, the district court's statement in Boumediene that "the information in the classified intelligence report, relating to the credibility and reliability of the source, was undoubtedly sufficient for the intelligence purposes for which it was prepared"-but that it was not adequate to satisfy the government's burden in court. ${ }^{67}$ In $\mathrm{Ali}$ Ahmed v. Obama, the government sought to rely on a "mosaic theory" to prove petitioner's conduct in support of al-Qaida: "The Government argues ... that 'the evidence meshes together to demonstrate' that the Petitioner engaged in conduct that allows the executive to detain him." ${ }^{68}$ In rejecting its application to the case at hand, however, the court explained:

The Court understands from the Government's declarations, and from case law, that use of the mosaic approach is a common and well-established mode of analysis in the intelligence community. This may well be true. Nonetheless, at this point in this long, drawn-out litigation the Court's obligation is to make findings of fact and conclusions of law which satisfy appropriate and relevant legal standards as to whether the Government has

64 Id. at 2270.

65 Nor, for that matter, does it answer such basic questions as whether the court should review whether the executive had sufficient basis to detain at some previous time versus whether it has such evidence at the time of review.

66 See Al Mutairi v. United States, Civil Action No. 02-828 (CKK), 2009 WL 2364173, at *3 (D.D.C. July 29, 2009) ("One of the central functions of the Court in this case is 'to evaluate the raw evidence' proffered by the Government and to determine whether it is 'sufficiently reliable and sufficiently probative to demonstrate the truth of the asserted proposition with the requisite degree of clarity."')(internal citations omitted) See also Parhat v. Gates, 532 F.3d 834 (D.C. Cir. 2008) (finding inadequate the Government's evidentiary basis for CSRT decisions).

67 See supra note 33 and accompanying text.

${ }^{68}$ Ali Ahmed v. Obama, 613 F. Supp. 2d 51, 55-56 (D.D.C. 2009). 
proven by a preponderance of the evidence that the Petitioner is justifiably detained. $^{69}$

The district court went on to state: "The kind and amount of evidence which satisfies the intelligence community in reaching final conclusions about the value of information it obtains may be very different, and certainly cannot govern the Court's ruling., 70

It is difficult to generalize much from these few district court snippets in part because they can be read in several ways. Are the courts saying that the specific evidentiary submissions by the government in those particular cases were, once scrutinized in court, shown to be too unreliable? Or are they saying that the types of information relied on by the government to form its assessments of who is or is not an enemy fighter are unsuitable generally as proof in court reviews of detention? And if the latter, are the courts saying that, while recognizing the legal appropriateness of reliance on intelligence information to support detention in far away combat zones, they are unwilling to give a judicial imprimatur to similar reliance once a case reaches a courtroom? Or, going much further, are they saying that the law of war - even outside the reach of courts - demands the type and quality of evidence that would satisfy a court? The courts' posture with respect to evidentiary sufficiency lies ambiguously amid this spectrum.

Moreover, these statements by habeas courts rejecting the sufficiency of some government submissions raise important distinctions between "evidence" and "intelligence." Seen through the lens of the courtroom, a natural analytic starting point for assessing an individual's enemy status is evidence, or facts that are "furnished to a legal tribunal otherwise than by reasoning . ..."71 Seen, however, through the lens of a global "battlefield," a natural starting point is intelligence-informational assessments and edu-

69 Id. at 56 (footnote omitted).

70 Id. See also Al-Adahi v. Obama, No. 05-280, slip op. at 5 (D.D.C. Aug. 21, 2009) ("The kind and amount of evidence which satisfies the intelligence community in reaching final conclusions about the value of information it obtains may be very different from, and certainly cannot determine, this Court's ruling.").

71 See 1 John Henry Wigmore, Evidence in Trials at Common LaW §1, at 11 (1983); see also Bostan v. Obama, No. 05-883, slip op. at 10 n.5 (D.D.C. Aug. 19, 2009), available at https://ecf.dcd.uscourts.gov/cgi-bin/show_public_doc?2005cv2386-1408 (applying Federal Rules of Evidence to Guantánamo habeas cases, "except where national security concerns or undue burden to the government requires otherwise."). See also id. at 6-7 ("The very notion that the Court should lower its standards of admissibility to whatever level the government is prepared (or even able) to satisfy is contradictory to the fundamental principles of fairness that inform the Great Writ's existence."). 
cated judgments that the executive relies on in making tactical and operational decisions. ${ }^{72}$

Evidence assessment and intelligence assessment are similar but not identical processes, in part because their purposes differ. Both seek truth, though in the case of evidence in the American justice system it is taken as an article of faith that adversarial contestation will generally enhance it, ${ }^{73}$ whereas intelligence collection and assessment is often a unilateral endeavor relying on interpretation and reasoned assessment amid uncertainties to guide government actions, and is often conducted and recorded with little regard for eventual courtroom use. ${ }^{74}$ Moreover, the law of evidence serves not only to promote accuracy but also to protect justice and fairness $;{ }^{75}$ intelligence, by contrast, is generally unconcerned with balancing competing values. ${ }^{76}$

Lest one think these are merely semantic or inconsequential distinctions, consider that beyond Guantánamo it is sometimes those same "intelligence purposes" viewed skeptically by the courts upon which the executive relies in making decisions of enormous military and humanitarian or liberty consequences. These include detention decisions in Afghanistan, where recently revised Department of Defense guidelines establish military review panels applying a preponderance of evidence standard to all reasonably

72 See Joint Chiefs of Staff, Joint Pub. 1-02, DePartment of Defense Dictionary of Military And Associated Terms 208 (2001 as amended through Aug. 2009); Central InTELLIGENCE AGENCY, A CONSUMER's Guide to InTELLIGENCE at vii (1999).

73 See Matthew T. King, Security, Scale, Form and Function: The Search for Truth and the Exclusion of Evidence in Adversarial and Inquisitorial Justice Systems, 12 INT'L LEGAL PersP. 185, 188-89. See also Henry J. Friendly, Some Kind of Hearing, 123 U. PA. L.REV 1267, 1283 (citing Wigmore and stating that cross-examination "is beyond any doubt the greatest legal engine ever invented for the discovery of truth.").

74 See Wilber, supra note 2 (reporting controversy over whether government's Guantánamo habeas cases are flimsy or involve evidence "collected on chaotic battlefields for intelligence purposes, not for a courtroom."). As the Wall Street Journal editorial page put it, "[T]he truth is that in the fog of battle it is impossible to gather evidence the way a Manhattan cop can. There's no 'CSI: Kandahar."' Editorial, The Enemy Detainee Mess, WALL ST. J., July 3, 2008, at A10.

75 See FED. R. EvID. 102 (stating "These rules shall be construed to secure fairness in administration, elimination of unjustifiable expense and delay, and promotion of growth and development of the law of evidence to the end that the truth may be ascertained and proceedings justly determined.").

76 This paper does not deal with the many complex issues surrounding classified evidence in detention hearings, and the special problems that come with trying to declassify information or provide suspects or counsel with adequate substitutes. See, e.g., Attorney General Michael B. Mukasey, Remarks at the American Enterprise Institute for Public Policy Research (July 21, 2008), available at http://www.justice.gov/archive/ag/speeches/ 2008/index.html. For a general discussion of these issues in the criminal context, see SERRIN Turner \& Stephen J. Schulhofer, Brennan Center for Justice, The Secrecy Problem IN TERRORISM TRIALS (2005). 
available information. ${ }^{77}$ They also include the application of lethal force, both in the heat of battle as well as from afar using, for example, aerial drones against suspected al-Qaida figures. ${ }^{78}$ According to one report, in 2008 the U.S. government ratcheted up drone attacks on al-Qaida affiliated militants in Pakistan in part by lowering the standards that govern targeting: "We got down to a sort of 'reasonable man' standard . . . . If it seemed reasonable, you could hit it." 79

Besides raising important questions about the appropriate standards of proof, the statements quoted above from district courts reflect an attitude that judicial scrutiny of information or evidence is a fundamentally different exercise than the type of military decision-making that, beyond Guantánamo, currently remains outside the reach of judicial review. If so, this suggests that the application of judicial review to Guantánamo cases has not merely added a layer of procedural rigor, but in doing so has altered the analytic processes being applied to available information.

One example of this tension between evidence and intelligence standards is the case of Al Mutairi v. United States, described above. The district court credited the government's evidence that petitioner's travel route into Afghanistan matched that used by an al-Qaida affiliated group to smuggle individuals into Afghanistan to wage jihad; that his travel within Afghanistan coincided with that of fleeing al-Qaida fighters; and that some facts about his passport were consistent with an individual who has undergone al-Qaida training. ${ }^{80}$ The district court also found that Al Mutairi's own story lacked credibility. ${ }^{81}$ But the district court was unsatisfied with the government's case because it could not prove that petitioner did, in fact, train with al-Qaida or allied groups, or where he did so: "the Government

77 See Department of Defense, Detainee Review Procedures at Bagram Theater Internment Facility (BTIF), Afghanistan (U), available at http://www.scotusblog.com/wp/wpcontent/uploads/2009/09/addendum.pdf (last visited Oct. 31, 2009).

78 See Peter Bergen \& Katherine Tiedemann, The Drone War, NEw REPUBLIC, June 3, 2009, http://www.tnr.com/article/the-drone-war; Jane Mayer, The Predator War, NEw YORKER, Oct. 26, 2009, at 36, 42-45 (detailing use of missile strikes against suspected terrorists amid imperfect intelligence, and resulting errors); Josh Meyer, CIA Expands Use of Drones in Terror War, L.A. TimeS, Jan. 29, 2006, at A1 ("In February 2002, a Predator tracked and killed a tall man in flowing robes along the Pakistan-Afghanistan border. The CIA believed it was firing at Bin Laden, but the victim turned out to be someone else."). On legal issues of targeted killings, see Kenneth Anderson, Targeted Killing in U.S. Counterterrorism Strategy and Law (May 11, 2009), http:/www.brookings.edu/papers/2009/0511_ counterrorism_anderson.aspx.

79 See David E. Sanger, The Inheritance: The World Obama Confronts and the Challenges to American Power 250 (2009).

${ }^{80}$ Al Mutairi v. United States, Civil Action No. 02-828 (CKK), 2009 WL 2364173, at*14 (D.D.C. July 29, 2009).

81 Id. 
has not filled in these blanks . .. with sufficiently credible and reliable evidence to meet its burden . . . ."82 It may well be that under these facts the government ought not to be able to detain someone, either as a matter of law or policy. But it also seems quite likely that a reasonable intelligence officer might assess this case very differently, especially operating from a baseline expectation that some "blanks" are to be expected in many cases and require informed but speculative judgment to fill them. ${ }^{83}$

To say that the information and analytic processes relied upon by the executive in performing its military functions are unsuitable in court would go beyond merely rejecting the executive's assertion in the $2004 \mathrm{Su}-$ preme Court litigation that military tactical decisions - including whom to capture - are beyond the reach and competency of courts. Courts could have answered that claim, for example, by insisting on a role for judicial review of detention but then inquiring deferentially whether the government's own analytic assessment was reasonable. ${ }^{84}$ That is essentially what the Israeli Supreme Court did in its 2006 decision upholding but limiting the executive's authority for "targeted killings" of terrorist leaders - another controversial security measure that relies critically on intelligence information, sometimes amid clouds of uncertainty:

[A military strike targeting suspected terrorists] is the responsibility of the executive branch. It has the professional-security expertise to make that decision. The Court will ask itself if a reasonable military commander could have made the decision which was made. The question is whether the decision of the military commander falls within the zone of reasonable activity on the part of the commander. If the answer is yes, the Court will not exchange the military commander's security discretion with the security discretion of the Court. ${ }^{85}$

$82 I d$.

83 In this regard, circumstantial evidence is one criminal law context in which there is less distinction between evidence and intelligence analysis.

84 See generally Robert M. Chesney, National Security Fact Deference, 95 VA. L. REV. 1361 (2009). See also Fallon and Meltzer, supra note 18, at 2095 ("[A] court exercising habeas jurisdiction immediately confronts a 'scope of review' question: it could, for example, make an independent determination with no deference to the prior executive judgment, exercise review but exhibit some deference, or defer completely by withholding review of the issue altogether.").

85 Pub. Comm. Against Torture in Isr. v. Gov't of Isr., HCJ 769/02, at 57 (Dec. 14, 2006), available at http://elyon1.court.gov.il/files_eng/02/690/007/A34/02007690.a34.pdf (citing Aga v. The Commander of IDF Forces in the Gaza Strip Area, HCJ 1005/89, 44(1) PD 536, 539; Ajuri v. The Military Commander of the Judea and Samaria Area, HCJ 7015/02, 56(6) PD 352, 375). See also Amos N. Guiora, License to Kill, ForeIGN PoL'y (July 13, 2009), http://www.foreignpolicy.com/articles/2009/07/13/licence_to_kill (stating "[t]he basis for the attack is intelligence information that meets a four part test: Is it reliable, 
One might immediately object that targeted killing is a very different application of coercive state power than detention. Of course it is. ${ }^{86}$ But the ways in which it is different and the manner in which those distinctions ought to influence the institutional decision-making balance among the branches of government are complex questions left open by Boumediene, and only their surface is being scratched in Guantánamo habeas cases. ${ }^{87}$

\section{LOOKING FORWARD}

At the time of this writing, it remains unclear which branch or branches of government will resolve these questions of proof and evidence standards for future detention decisions, let alone where to set that line. ${ }^{88}$ However, this brief examination of some of the few district court cases that have dealt with the issue yields several insights or questions that should guide further legal development as the U.S. government contemplates a post-Guantánamo future.

First, embedded in the seemingly simple exercises of setting a standard of proof and sufficiency of evidence standard for judicial review of detention decisions are fundamental choices about balancing risks (errone-

credible, valid and viable? Given the stakes, corroborated information is significantly preferable to information that comes from a single source.").

86 See Waxman, supra note 5, at 1402-29.

87 To the extent that one looks to other federal habeas or appellate contexts by analogy, there are several different frames through which to consider appropriate judicial posture. One might, for example, look to rigorous federal habeas evidentiary hearings in cases where the prior state fact-finding or evidentiary hearing is considered inadequate. See Townsend v. Sain, 372 U.S. 293, 312-18 (1963); HeRTZ \& Liebman, supra note 17, at § 20.3(d)-(f). On the other hand, one might analogize Guantánamo-type detention habeas cases to federal appellate review of probable cause determinations by police, or other such context-sensitive discretionary decision-making. In Ornelas v. United States, 517 U.S. 690 (1996), the Court held that:

[A]s a general matter determinations of reasonable suspicion and probable cause should be reviewed de novo on appeal. Having said this, we hasten to point out that a reviewing court should take care both to review findings of historical fact only for clear error and to give due weight to inferences drawn from those facts by resident judges and local law enforcement officers.

Id. at 699 . The Court reasoned that "a police officer views the facts through the lens of his police experience and expertise. The background facts provide a context for the historical facts, and when seen together yield inferences that deserve deference." Id.

88 President Obama pledged to work with Congress in fashioning a post-Guantánamo legal framework that includes a strong role for courts. See President Barack Obama, Remarks by the President on National Security at the National Archive (May 21, 2009), available at http://www.whitehouse.gov/the_press_office/Remarks-by-the-President-On-National-

Security-5-21-09/. Since then, however, the White House has signaled that it will not seek legislation to regulate detention of Guantánamo detainees. See Peter Finn, Administration Won't Seek New Detention System, WASH. Post, Sept. 24, 2009, at A10; Anne E. Kornblut \& Dafna Linzer, White House Regroups on Guantanamo, WASH. Post, Sept. 25, 2009. 
ous long-term deprivation of liberty versus letting a terrorist go free), distributing those risks between captured individuals and society threatened by terrorism, and relying on judicial scrutiny versus deference to military or executive decision-making. ${ }^{89}$ The law of war vests considerable discretion in military commanders because judgments balancing humanitarian harms and military necessity are so context-dependent, often involving tremendous potential risks in either direction. Procedural due process doctrine only rarely confronts similarly dire consequences of both false positives and false negatives, and even more rarely without statutory guidance or some other constitutional or common law principles about how to balance those risks.

Second, if the hypothesis of Part III is correct - that in assessing the sufficiency of the government's case courts are subtly transforming not just the procedures of review but the nature of the factual evaluation- then the current gulf between legal regulation of detention at Guantánamo and elsewhere is wider than may be supposed. The standards of proof and evidence relied on by the executive outside of Guantánamo to detain under the same wartime legal authorities may be lower than those being applied to Guantánamo or may involve very different types of information and analytic processes. ${ }^{90}$ Such disparities could not only inadvertently skew incentives regarding where the executive will hold detainees but would raise considerably the stakes of ongoing litigation about whether habeas rights extend to detainees held in Afghanistan. ${ }^{91}$

Given the significant and long-term public policy import of the underlying risk calibration questions, Congress ought to play a significant role

89 See Fallon \& Meltzer, supra note 18, at 2069 ("Modern notions of deference to administrative decisionmakers, developed primarily in other contexts, are in considerable tension with the historic office of the Great Writ.").

90 On the application of the law of war to U.S. detention operations in Afghanistan, see Matthew C. Waxman, United States Detention Operations in Afghanistan and the Law of Armed Conflict, 39 IsR. Y.B. Hum. RTS. 161 (2009).

91 To date, there has been limited litigation dealing with this issue; only one court has squarely addressed the question of habeas rights for Bagram detainees. See Maqaleh v. Gates, 604 F. Supp. 2d 205 (D.D.C. 2009). In that case, Judge Bates held that three out of four detainees before him were entitled to habeas protection; the fourth could not invoke the Suspension Clause due to his Afghan citizenship. Id. at 209. There was, however, no discussion as to the standards of proof or evidence being applied in that case, as the court did not reach the merits of the habeas petitions. Rather, the court decided the as applied constitutionality of a statute amending federal habeas jurisdiction, and even this limited holding was stayed several months later in the face of a government motion to stay the decision pending appeal. See Maqaleh v. Gates, Civil Action No. 06-1669, slip op. at 1, 9-10 (D.D.C. June 1, 2009), available at http:/www.scotusblog.com/wp/wp-content/uploads/2009/06/bagramorder-6-1-09.pdf. See also Warren Richey, Next Flash Point over Terror Detainees: Bagram Prison, Christian SCI. Monitor, Feb. 12, 2009, available at http://www.csmonitor.com/ 2009/0212/p01s01-usmi.html; Charlie Savage, Embracing Bush Argument, Obama Upholds Detainee Policy in Afghanistan, N.Y. TIMES, Feb. 22, 2009, at A6, available at http://www.nytimes.com/2009/02/22/washington/22bagram.html. 
in helping to resolve them. ${ }^{92}$ Until now, these issues have largely been worked out through a back and forth struggle between the executive and the courts. In the 2005 Detainee Treatment Act, Congress touched on the proof standard issue obliquely in mandating that federal court review of Guantánamo detentions would be limited to:

(i) [W] hether the status determination of the Combatant Status Review Tribunal with regard to such alien was consistent with the standards and procedures specified by the Secretary of Defense for Combatant Status Review Tribunals (including the requirement that the conclusion of the Tribunal be supported by a preponderance of the evidence and allowing a rebuttable presumption in favor of the Government's evidence); and $^{93}$ (ii) to the extent the Constitution and laws of the United States are applicable, whether the use of such standards and procedures to make the determination is consistent with the Constitution and laws of the United States. ${ }^{94}$

But at that time Congress and the executive were trying to restrict judicial reconsideration of the underlying factual claims, and the rest of the statute gave the executive wide latitude to determine appropriate informational assessment standards and processes. ${ }^{95}$ Besides the fact that the Combatant Status Review Tribunal process was held to be an inadequate substitute for habeas corpus in Boumediene, several major factors argue in favor of thoroughly re-examining previous policy assumptions. Those factors include better knowledge about the detainee population at Guantánamo and elsewhere, the evolving nature of the transnational terrorism threat, the capacity of the government to make "accurate" determinations of dangerousness, and the development or enhancement of other government counterterrorism tools and legal authorities to combat threats. Congress ought therefore consider whether innovative approaches to the standard of proof and evidence questions - beyond both the usual habeas approach and the usual law of war approach - might best balance competing interests. For example, legislation regulating detention might escalate the required standard of proof in periodic review by a court, beginning with a relatively low

92 See Benjamin Wittes \& Jack Goldsmith, Will Obama Follow Bush or FDR?, WASH. Post, June 29, 2009, at A17 (discussing and criticizing both a unilateral executive approach and the lengthy legislative approach to dealing with terrorist detainees); David A. Martin, Offshore Detainees and the Role of Courts After Rasul v. Bush: The Underappreciated Virtues of Deferential Review, 25 B.C. THIRD WORLD L.J. 125 (Winter 2005) (proposing a system with limited habeas review in which courts would defer to military factfinding but would retain authority to consider validity of tribunal procedures and the substantive standards governing "enemy combatant" classifications).

93 See Waxman, supra note 5, at 1408-12.

94 Detainee Treatment Act of 2005, Pub. L. No. 109-148, § 1005, 119 Stat. 2680, 2742.

95 See Janet Cooper Alexander, Jurisdiction-Stripping in the War on Terrorism, 2 STAN. J. C.R. \& C.L. 259, 260-67 (2006); Fallon \& Meltzer, supra, note 18, at 2060. 
standard to justify short-term detention but a much more rigorous standard beyond a certain duration. ${ }^{96}$

Analysis of the Guantánamo habeas cases shows that seemingly straightforward issues of proof and evidentiary standards depend heavily on the appropriate baseline: war versus peacetime, military discretion based on intelligence versus law enforcement discretion based on evidence. In 2004, when the Supreme Court decided Hamdi, courts generally seemed to favor the former. By 2009, there has been a largely unspoken drift by courts toward the latter. Ultimately, effective institutional reform will require viewing the problem from a perspective that combines features of courtroom justice and battlefield combat, evidentiary scrutiny and intelligence analysis.

96 See Waxman, supra note 5, at 1408-12. 